\title{
IMPLEMENTASI GOOD CORPORATE GOVERNANCE (GCG) DALAM MENGUKUR RISIKO DAN KINERJA KEUANGAN BANK SYARIAH DI INDONESIA
}

\author{
Yudhistira Ardana \\ STMIK Pringsewu \\ ardanayudhistira@gmail.com
}

\begin{abstract}
Abtract
Good Corporate Governance (GCG) is one of the key elements in increasing economic efficiency that can help create a conducive and accountable relationship between elements of a company (board of commissioners, board of directors, and shareholders) in order to improve the company's financial performance. This study aims to reveal the influence of Good Corporate Governance (GCG) which is proxied by managerial ownership, institutional ownership, independent board of commissioners and sharia supervisory board in measuring the risk of financing and financial performance of Islamic banks in Indonesia. The results of this study as a whole can be concluded that, Good Corporate Governance (GCG) in measuring risk and financial performance of Islamic banks has no significant effect.
\end{abstract}

Keywords: GCG, Financing Risk, Financial Performance, Islamic Banking 


\section{A. LATAR BELAKANG}

Sebagai salah satu negara berkembang, Indonesia selalu berupaya untuk menjadi negara yang mampu memperbaiki sistem ekonomi dengan memperbaiki sistem kerja dan peluang usaha yang bisa dimanfaatkan sebagai upaya menuju pertumbuhan ekonomi yang dapat bersaing dengan negara lain. Bank merupakan salah satu aspek penting dalam kegiatan perekonomian modern. Bank berperan sebagai fasilitator dalam lalu lintas kegiatan permodalan dan pembayaran yang menjadi salah satu kunci pertumbuhan kegiatan ekonomi. Selain itu bank juga merupakan lembaga pengelola keuangan yang memiliki fungsi dominan dalam pergerakan ekonomi masyarakat. Berdasarkan pola pengoperasiannya bank dibedakan menjadi dua yaitu bank konvensional dan bank syariah.

Lahirnya Undang-Undang Nomor 21 tentang Perbankan Syariah pada tahun 2008 mendorong eksistensi perkembangan industri Perbankan Syariah di Indonesia saat ini cukup pesat. Terbukti pada salah satu Bank Syariah di Indonesia yaitu Bank Syariah Mandiri yang dilihat dari aset perbankannya, berdasarkan annual report BSM tahun 2016 menyatakan adanya pertumbuhan sebesar $12,02 \%$. Hal ini dapat memberikan dampak yang baik terhadap kinerja perbankan syariah.

Kinerja keuangan bank adalah suatu gambaran sampai mana tingkat keberhasilan yang dicapai oleh bank dalam kegiatan operasionalnya. Kinerja keuangan perbankan menjadi faktor utama dan sangat penting untuk menilai keseluruhan kinerja perbankan itu sendiri. Mulai dari penilaian aset, utang, likuiditas dan lain sebagainya. Kinerja suatu bank dapat dinilai dengan melakukan analisis terhadap laporan keuangannya. Berdasarkan laporan itu dapat dihitung rasio keuangan untuk menilai tingkat kesehatan bank. Analisis rasio keuangan tersebut memungkinkan manajemen mengidentifikasi keberhasilan bank dalam melakukan kegiatan operasionalnya. Analisis rasio keuangan juga dapat membantu para pelaku bisnis untuk menilai kinerja bank.

Krisis ekonomi global yang terjadi beberapa waktu yang lalu memberikan dampak yang tidak baik terhadap kinerja keuangan perusahaan hingga saat ini. Salah satu faktor penyebab terjadinya krisis keuangan perusahaan karena lemahnya implementasi sistem tata kelola perusahaan atau Corporate Governance (Eksandy, 2018). Good Corporate Governance (GCG) merupakan isu dalam mengelola suatu perusahaan pada saat ini. Dengan adanya kejadian yang berturut-turut dalam suatu peristiwa yang menimpa perusahaan besar, maka dapat menyadarkan banyak pihak diseluruh dunia mengenai pentingnya pelaksanaan pengelolaan perusahaan yang baik dan benar. Untuk itu berbagai cara dilakukan oleh banyak pihak untuk mendapatkan kesepakatan mengenai parameter-parameter yang akan digunakan untuk 
mengukur sebuah pelaksanaan konsep Good Corporate Governance (GCG) yang ada di dalam suatu perusahaan.

Hussain \& Al-Ajmi (2012) mengemukakan bahwa peranan penting dalam manajemen risiko adalah dengan diterapkannya corporate governance di perbankan syariah. Todorovic (2013) mengatakan bahwa good corporate governance dapat membantu mencegah skandal perusahaan, fraud, dan potensi tanggung jawab perdata dan pidana perusahaan. Risiko di perbankan syariah yang lebih kompleks daripada perbankan konvensional yaitu, fiduciary money, fluktuasi suku bunga, piutang gagal bayar, kesalahan operasional dan lain-lain, juga menuntut para pelaku bisnis keuangan syariah lebih pruden termasuk didalamnya pengawasan dan kontrol yang berfungsi baik. Disinilah perlunya peningkatan pelaksanaan good corporate governance dalam institusi Perbankan Syariah.

Salah satu aspek yang terkandung di dalam Good Corporate Governance (GCG) adalah struktur kepemilikan. Struktur kepemilikan merupakan salah satu mekanisme yang digunakan dalam sistem Good Corporate Governance (GCG) untuk melakukan pengukuran kinerja. Beberapa aspek yang terkait di dalam struktur kepemilikan diantaranya kepemilikan institusional, kepemilikan manajerial, dewan komisaris independen, dewan direksi, dan komite audit. Hal ini sejalan dengan Sunarwan (2015) menerangkan bahwa Good Corporate Governance (GCG) merupakan salah satu elemen kunci dalam meningkatkan efisiensi ekonomis yang dapat membantu terciptanya hubungan yang kondusif dan dapat dipertanggungjawabkan diantara elemen suatu perusahaan (dewan komisaris, dewan direksi, dan para pemegang saham) dalam rangka meningkatkan kinerja keuangan perusahaan.

Penelitian terdahulu telah menguji mengenai dampak Good Corporate Governance (GCG) terhadap kinerja bank dilakukan oleh Maurya, et al (2015) menyatakan bahwa Good Corporate Governance (GCG) yang diproksikan dengan composition of the board, jumlah komite, jumlah dewan pengawas syariah berpengaruh positif terhadap kinerja keuangan. Pada hasil penelitian Tertius dan Christiawan (2015) menyatakan bahwa komisaris independen berpengaruh negatif terhadap ROA. Magdalena et al (2017) menyatakan bahwa Proporsi Dewan Komisaris Independen berpengaruh negatif terhadap kinerja keuangan perbankan syariah, sementara variabel Dewan Pengawas Syariah dan Proporsi Komite Audit Independen tidak berpengaruh terhadap Kinerja. Penelitian Sriwedari (2012) menunjukkan bahwa kepemilikan institusional, kepemilikan manajerial, proporsi dewan komisaris independen, komite audit dan manajemen laba memberikan pengaruh negatif tidak signifikan terhadap kinerja keuangan. 
Penelitian Eksandy (2018) Dewan Direksi berpengaruh terhadap kinerja keuangan, sementara Komisaris Independen, Dewan Pengawas Syariah dan Komite Audit tidak berpengaruh terhadap kinerja keuangan. Agustia (2013) memperoleh hasil good corporate governance (ukuran komite audit, proporsi komite audit independen, kepemilikan institusional dan kepemilikan manajerial) tidak berpengaruh signifikan terhadap manajemen laba, sedangkan leverage berpengaruh, free cash flow berpengaruh negatif dan signifikan terhadap manajemen laba. Hasil penelitian Khafid (2012) menunjukkan bahwa komposisi dewan komisaris, kepemilikan saham oleh manajemen/ kepemilikan manajerial, dan komite audit terbukti secara signifikan berpengaruh terhadap persistensi laba. Sedangkan kepemilikan institusional tidak berpengaruh secara signifikan terhadap persistensi laba. Hasil penelitian Eliyanora dan Veronica (2014) menyatakan bahwa komisaris independen tidak berpengaruh secara signifikan terhadap NPL. Guna dan Herawaty (2010) menghasilkan kepemilikan institusional, kepemilikan manajemen, komite audit, komisaris independen, independensi dan ukuran perusahaan tidak berpenga-ruh terhadap manajemen laba.

Sementara itu, penelitian Heneetigala dan Armstrong (2011), Mohammed dan Fatimoh (2012), Rehman dan Mangla (2012), Ghaffar (2014) menyatakan bahwa variabe GCG mempunyai pengaruh positif dan signifikan terhadap kinerja keuangan perusahaan. Hal tersebut menunjukkan bahwa perusahaan yang menerapkan strategi GCG dapat meningkatkan kinerja perusahaan. Namun demikian sebagian penelitian menunjukan hasil yang berbeda. Paul (2015) menyatakan bahwa tidak ada pengaruh antara GCG terhadap kinerja keuangan bank mikro (bank microfinance) di Nigeria. Penelitian Syam dan Nadja (2012), Permatasari dan Novitasary (2014) juga menyatakan bahwa tidak ada pengaruh penerapan GCG terhadap kinerja keuangan perusahaan.

Bisnis perbankan tidak lepas dari risiko kegagalan dalam mengembalikan pembiayaan yang disalurkan (Siswanti, 2016). Hal tersebut membuat bank syariah harus selalu menjaga tingkat Non Performing Financing (NPF). Tingkat NPF dapat ditekan melalui penerapan GCG yang baik dan benar. Hal ini ditunjukkan oleh hasil penelitian Switzer dan Wang (2013), Permatasari dan Novitasary (2014), serta Bourakba dan Zerargui (2015) menyatakan bahwa GCG mempunyai pengaruh negatif dan signifikan terhadap risiko kredit suatu bank. Artinya, jika implementasi GCG dilakukan dengan baik maka dapat menurunkan tingkat risiko kredit.

Melihat masih banyaknya gap antara hasil penelitian terahulu, maka penulis tertarik untuk melakukan pengembangan penelitian dengan judul Good Corporate Governance (GCG) dan Kinerja Keuangan Bank Syariah 
di Indonesia dengan variabel GCG diproksikan oleh kepemilikan manajerial, kepemilikan institusional, dewan komisaris independen dan dewan pengawas syariah, sedangkan kinerja keuangan bank syariah diproksikan risiko kredit dan profitabilitas.

\section{B. METODE}

Penelitian ini merupakan penelitian kuantitatif dengan pendekatan statistik untuk mencari hubungan kausal (sebab-akibat). Populasi yang digunakan dalam penelitian ini adalah seluruh industri perbankan umum syariah yang terdaftar di Indonesia sesuai dengan statistik perbankan syariah yang dipublikasikan Bank Indonesia tahun 2018. Sampel dalam penelitian berjumlah 42. Penelitian ini memakai metode purposive sampling dengan kriteria sebagai berikut:

1. Bank Syariah yang mempublikasi laporan keuangan tahunan periode 2008, 2011, 2014, 2017

2. Bank Syariah yang mempublikasikan laporan GCG tahunan periode 2008, 2011, 2014, 2017

Jenis data yang digunakan di dalam penelitian ini adalah data sekunder. Data yang diperlukan adalah data laporan keuangan dan laporan Good Corporate Governance (GCG) perusahaan bank umum syariah yang dapat diperoleh dari situs website perusahaan dan data penelitian sebelumnya. Dari kriteria tersebut maka diperoleh sampel sebanyak 13 perusahaan perbankan syariah. Dalam penelitian ini penulis menggunakan analisis Ordinary Least Square (OLS) untuk mengolah data yang tersedia. Analisis model OLS pada dasarnya adalah analisis data time series yang digunakan untuk variabel-variabel yang memiliki ketergantungan satu variabel dependen dengan satu atau lebih variabel independen. Model OLS merupakan metode regresi yang meminimalkan jumlah kesalahan (error) kuadrat. Model regresi linier yang dipakai dengan metode OLS tersebut, harus memenuhi asumsi BLUE (Best Linear Unbiased Estimator) dalam melakukan pendugaan interval dan pengujian parameter regresi populasi. Dalam menganalisis data-data yang telah dikumpulkan akan digunakan model ekonometrika. Model OLS ini digunakan untuk mengetahui pengaruh kepemilikan manajerial, kepemilikan institusional, dewan komisaris independen dan dewan pengawas syariah terhadap risiko pembiayaan serta terhadap kinerja keuangan bank syariah di Indonesia. Pengolahan data dalam penelitian ini menggunakan bantuan software Microsoft Excel 2013 dan Eviews 10. Model yang digunakan dalam penelitian ini yaitu sebagai berikut 
Model regresi 1 : penerapan GCG dalam mengukur risiko perbankan syariah

$$
N P F_{i t}=a+B 1 K I_{i t}+B 2 K M_{i t}+B 3 U D K I_{i t}+B_{3 U D P S} i t+e_{i t}
$$

Model regresi 2 : penerapan GCG dalam mengukur kinerja perbankan syariah

$$
R O A_{i t}=a+B 1 K I_{i t}+B 2 K M_{i t}+B 3 U D K I_{i t}+B 3 U D P S_{i t}+e_{i t}
$$

\section{PEMBAHASAN}

Ada beberapa tahapan yang harus dilalui dalam melakukan uji model regresi linier yang dipakai dengan metode OLS. Hal yang dilakukan pertama kali yaitu melakukan uji asumsi klasik seperti uji multikolinieritas, uji autokorelasi dan uji heteroskedastisitas. Berikut ini disajikan hasil uji multikolinieritas.

Tabel 1 Hasil Uji Multikolinieritas

\begin{tabular}{cccc}
\hline \hline & \multicolumn{3}{c}{ Uncentere } \\
Variable & $\begin{array}{c}\text { Coefficient } \\
\text { Variance }\end{array}$ & $\begin{array}{c}\mathrm{d} \\
\text { VIF }\end{array}$ & $\begin{array}{c}\text { Centered } \\
\text { VIF }\end{array}$ \\
\hline \hline $\mathrm{C}$ & 0.003526 & 141.1134 & $\mathrm{NA}$ \\
$\mathrm{KI}$ & 0.002269 & 81.84116 & 1.246744 \\
$\mathrm{KM}$ & 0.771840 & 1.103114 & 1.017316 \\
UDKI & 0.001028 & 16.22337 & 1.511734 \\
UDPS & 0.000130 & 30.23343 & 1.436749 \\
\hline \hline
\end{tabular}

Berdasarkan dari hasil uji multikolinieritas pada tabel 1 dapat disimpulkan bahwa tidak ada korelasi antara masing-masing variabel bebas dengan variabel dependen (NPF dan ROA), sehingga layak digunakan untuk analisis selanjutnya karena nilai centered VIF $<10$.

Kemudian dilanjutkan dengan uji autokorelasi. Uji Autokorelasi diartikan sebagai korelasi yang terjadi antara komponen-komponen dari serangkaian observasi yang dilakukan baik dalam bentuk berderetan waktu (time series data) ataupun korelasi antara tempat berdekatan (cross section data). Berikut adalah hasil dari perhitungan uji autokorelasi sehingga di dapatkan hasil berupa nilai statistik Durbin Watson: 
Tabel 2 Hasil Uji Autokorelasi

\begin{tabular}{lclc}
\hline \hline F-statistic & 0.902295 & $\begin{array}{l}\text { Prob. F(2,35) } \\
\text { Prob. Chi- }\end{array}$ & 0.4149 \\
Obs ${ }^{\star}$ R-squared & 2.059330Square(2) & 0.3571 \\
\hline \hline
\end{tabular}

Dari hasil uji autokorelasi pada tabel 2, terlihat bahwa nilai DurbinWatson sebesar 2,059. Nilai tersebut akan dibandingkan dengan hasil nilai dari tabel signifikansi Durbin-Watson dengan jumlah sampel yang digunakan sebanyak $42(n=42)$ dan jumlah variabel independen yang dipakai adalah $4(\mathrm{k}=4)$. Maka diperoleh hasil pada tabel dU adalah 1,7202 dan dL sebesar 1,3064. Nilai DW pada hasil uji autokorelasi pada penelitian ini adalah sebesar 2,059, nilai tersebut lebih besar dari nilai dU dan kurang dari nilai $(4-\mathrm{dU})=2,190$. Sehingga dapat disimpulkan bahwa tidak terdapat autokorelasi.

Selanjutnya yang harus dilakukan adalah menguji heteroskedastisitas. Kriteria pengujian heteroskedastisitas yaitu dengan membandingkan nilai probabilitas chi square dengan alpha (a) atau dapat juga membandingkan nilai chi square hitung dengan chi square kritis. Berikut disajikan hasil uji heteroskedastisitas.

Tabel 3 Hasil Uji Heteroskedastisitas

\begin{tabular}{|c|c|c|c|}
\hline F-statistic & 1.244218 & $\begin{array}{l}\text { Prob. F(4,37) } \\
\text { Prob. Chi- }\end{array}$ & 0.3092 \\
\hline Obs*R-squared & $4.979614 \varsigma$ & quare(4) & 0.2894 \\
\hline $\begin{array}{l}\text { Scaled explained } \\
\text { SS }\end{array}$ & $7.876132 \varsigma$ & $\begin{array}{l}\text { Prob. Chi- } \\
\text { quare }(4)\end{array}$ & 0.0962 \\
\hline
\end{tabular}

Dari tabel 3 dapat dilihat bahwa nilai probabilitas dari Obs $R$-Squared sebesar 4.979614. Hal tersebut menunjukan bahwa hasil tersebut lebih dari nilai kritis 5\% sehingga dapat diambil kesimpulan bahwa tidak terdapat heteroskedastisitas pada data yang digunakan dalam penelitian ini.

Setelah melakukan uji asumsi klasik, maka kemudian dilanjutkan dengan uji regresi model Ordinary Least Square (OLS). 
Tabel 4 Hasil Uji Regresi OLS Model 1

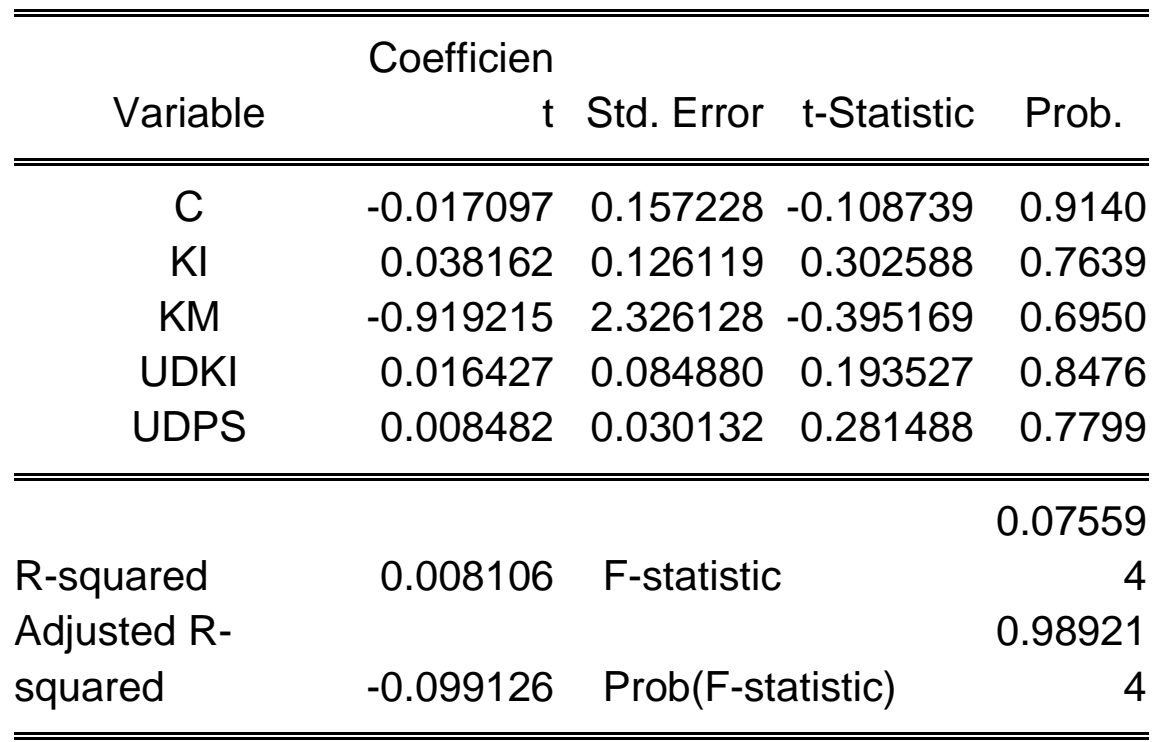

Berdasarkan hasil regresi yang telah dilakukan, diketahui bahwa nilai probabilitas (F-statistik) atau uji $F$ sebesar 0.075594. Dapat disimpulkan bahwa nilai $F$ statistik lebih dari nilai alpha yaitu sebesar $5 \%$ dan secara statistik dapat dikatakan tidak signifikan tetapi signifikan pada nilai alpha sebesar $10 \%$. Hal ini menunjukan bahwa variabel penerapan GCG secara simultan tidak berpengaruh signifikan dalam mengukur risiko pada perbankan syariah di Indonesia. Berdasarkan hasil estimasi pada Tabel 3, dapat diketahui bahwa nilai koefisien determinasi yang disesuaikan (Adjusted $R$ Square) sebesar 0.099126, artinya bahwa kemampuan variabel independen dalam menjelaskan perubahan nilai variabel dependen adalah sebesar 9,91\% dan sisanya sebesar 91,09\% dipengaruhi oleh faktor-faktor lain di luar model. Hasil penelitian ini didukung oleh hasil penelitian Switzer dan Wang (2013), Permatasari dan Novitasary (2014), serta Bourakba dan Zerargui (2015) menyatakan bahwa GCG mempunyai pengaruh negatif dan signifikan terhadap risiko kredit suatu bank.

Variabel kepemilikan institusional merupakan variabel yang mempengaruhi Non Performing Financing dengan koefisien regresi positif sebesar 0.038162 . Hasil tersebut menunjukan bahwa apabila kepemilikan institusional meningkat sebesar $1 \%$ maka Non Performing Financing akan meningkat sebesar 0.038162 dengan anggapan variabel yang lain konstan atau tetap.

Dilihat dari hasil uji $t$ atau uji individu diperoleh hasil bahwa nilai probabilitas untuk variabel kepemilikan institusional lebih besar dari nilai signifikansi yang telah ditentukan yaitu sebesar 0.7639 , artinya bahwa variabel kepemilikan institusional tidak memiliki pengaruh secara siginifikan terhadap risiko kredit yang diukur dengan Non Performing 
Financing (NPF). Hasil penelitian ini didukung oleh Agustia (2013) dimana dalam penelitian yang dilakukannya menemukan bahwa tingkat kepemilikan institusional tidak memiliki perngaruh terhadap manajemen laba.

Variabel kepemilikan manajerial (KM) merupakan variabel yang memiliki pengaruh koefisien regresi negatif sebesar -0.919215 pada Non Performing Financing. Hasil tersebut menunjukkan bahwa apabila kepemilikan manajerial (KM) meningkat sebesar $1 \%$ maka Non Performing Financing (NPF) akan menurun sebesar 0.919215 dengan anggapan variabel yang lain konstan atau tetap. Dilihat dari hasil uji t atau uji individu diperoleh hasil bahwa nilai probabilitas untuk variabel kepemilikan manajerial lebih besar dari nilai signifikansi yang telah ditentukan yaitu sebesar 0.6950 , artinya bahwa variabel kepemilikan manajerial tidak memiliki pengaruh secara siginifikan terhadap risiko kredit yang diukur dengan Non Performing Financing (NPF). Hal ini dapat terjadi kemungkinan karena tingkat kepemilikan manajerial pada bank syariah sangat rendah yang menyebabkan pihak manajemen belum dapat secara maksimal mengelola perusahaan dan tidak memiliki peran yang cukup besar dala pengambilan keputusan sehingga tidak berpengaruh terhadap risiko kredit yang diukur dengan NPF. Hasil ini bertolak belakang dengan penelitian yang dilakukan oleh Khafid (2012) yang mengungkapkan bahwa, kepemilikan saham oleh manajemen/kepemilikan manajerial, dan komite audit terbukti secara signifian positif berpengaruh terhadap persistensi laba. Namun hasil penelitian ini juga didukung oleh Agustia (2013) yang menemukan bahwa tingkat kepemilikan manajerial memang tidak berpengaruh terhadap manajemen laba.

Pada hasil uji variabel ukuran dewan komisaris independen (UDKI) menunjukkan pengaruh koefisien regresi positif sebesar 0.016427 pada Non Performing Financing. Hasil tersebut menunjukkan bahwa apabila ukuran dewan komisaris independen meningkat sebesar 1\% maka Non Performing Financing akan meningkat sebesar 0.016427 dengan anggapan variabel yang lain konstan atau tetap. Dilihat dari hasil uji t atau uji individu diperoleh hasil bahwa nilai probabilitas untuk variabel ukuran dewan komisaris independen lebih besar dari nilai signifikansi yang telah ditentukan yaitu sebesar 0.8476 , artinya bahwa variabel ukuran dewan komisaris independen tidak memiliki pengaruh secara siginifikan terhadap risiko kredit yang diukur dengan Non Performing Financing (NPF). Hasil penelitian ini sejalan dengan Eliyanora dan Veronica (2014) yang menemukan bahwa proporsi komisaris independen tidak berpengaruh secara signifikan terhadap pembiayaan bank. Hal ini disebabkan karena penempatan atau penambahan anggota komisaris independen hanya sekedar memenuhi ketentuan formal, sementara pemegang saham 
pengendali masih memegang peranan penting sehingga kinerja ukuran dewan komisaris independen tidak meningkat.

Variabel ukuran dewan pengawas syariah (UDPS) merupakan variabel yang mempengaruhi Non Performing Financing dengan koefisien regresi positif yakni sebesar 0.008482 . Hasil tersebut menunjukkan bahwa apabila ukuran dewan pengawas syariah meningkat sebesar $1 \%$ maka Non Performing Financing akan meningkat sebesar 0.008482 dengan anggapan variabel yang lain konstan atau tetap. Dilihat dari hasil uji t atau uji individu diperoleh hasil bahwa nilai probabilitas untuk variabel ukuran dewan pengawas syariah lebih besar dari nilai signifikansi yang telah ditentukan yaitu sebesar 0.7799 , artinya bahwa variabel ukuran dewan pengawas syariah tidak memiliki pengaruh secara siginifikan terhadap risiko kredit yang diukur dengan Non Performing Financing (NPF). Hal ini terjadi karena Dewan Pengawas Syariah yang ditunjuk biasanya hanya berdasarkan popularitas dan tokoh masyarakat untuk menaikkan citra dari bank syariah itu sendiri (Rahmat, 2017).

Tabel 5 Hasil Uji Regresi OLS Model 2

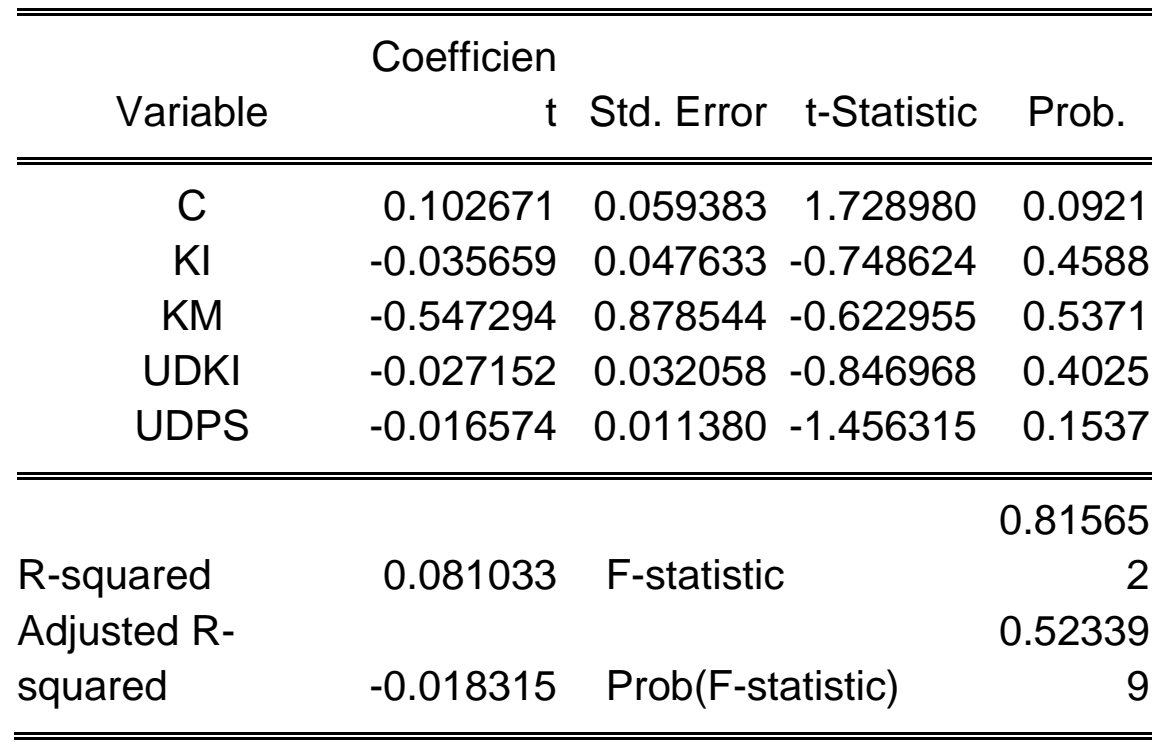

Berdasarkan hasil regresi yang telah dilakukan, diketahui bahwa nilai probabilitas (F-statistik) atau uji $F$ sebesar 0.815625. Dapat disimpulkan bahwa nilai $\mathrm{F}$ statistik lebih dari nilai alpha yaitu sebesar $5 \%$ dan secara statistik dapat dikatakan tidak signifikan. Hal ini menunjukan bahwa variabel penerapan GCG secara simultan tidak berpengaruh signifikan dalam mengukur kinerja keuangan pada perbankan syariah di Indonesia. Berdasarkan hasil estimasi pada Tabel 4, dapat diketahui bahwa nilai koefisien determinasi yang disesuaikan (Adjusted $R$ Square) sebesar 0.018315 , artinya bahwa kemampuan variabel independen dalam 
menjelaskan perubahan nilai variabel dependen adalah sebesar $1,83 \%$ dan sisanya sebesar $98,17 \%$ dipengaruhi oleh faktor-faktor lain di luar model. Hasil penelitian ini didukung Paul (2015) yang menyatakan bahwa tidak ada pengaruh antara GCG terhadap kinerja keuangan bank mikro (bank microfinance) di Nigeria. Penelitian Syam dan Nadja (2012), Permatasari dan Novitasary (2014) juga menyatakan bahwa tidak ada pengaruh penerapan GCG terhadap kinerja keuangan perusahaan.

Variabel kepemilikan institusional merupakan variabel yang mempengaruhi Return on Assets dengan koefisien regresi negatif sebesar -0.035659. Hasil tersebut menunjukan bahwa apabila kepemilikan institusional meningkat sebesar $1 \%$ maka Return on Assets akan menurun sebesar 0. 035659 dengan anggapan variabel yang lain konstan atau tetap. Dari hasil pengamatan pada hasil uji t atau uji individu diperoleh hasil bahwa nilai probabilitas untuk variabel kepemilikan institusional lebih besar dari nilai signifikansi yang telah ditentukan yaitu sebesar 0.4588 , artinya bahwa variabel kepemilikan institusional tidak memiliki pengaruh secara siginifikan terhadap profitabiltas yang diukur dengan Return On Assets (ROA). Hasil penelitian ini sejalan dengan Khafid (2012) yang menemukan bahwa kepemilikan institusional tidak berpengaruh secara signifian terhadap persistensi laba. Selain itu Sriwedari (2012) dalam penelitannya juga mengungkapkan bawa mekanisme Good Corporate Governance dalam hal ini kepemilikan institusional, kepemilikan manajerial, proporsi dewan komisaris independen dan komite audit secara bersama-sama tidak berpengaruh terhadap manajemen laba. Hasilnya menunjukkan pengaruh yang lemah.

Variabel kepemilikan manajerial (KM) merupakan variabel yang memiliki pengaruh koefisien regresi negatif sebesar -0.547294 pada Return on Assets. Hasil tersebut menunjukkan bahwa apabila kepemilikan manajerial (KM) meningkat sebesar $1 \%$ maka Return on Assets (ROA) akan menurun sebesar 0.547294 dengan anggapan variabel yang lain konstan atau tetap. Dilihat dari hasil uji t atau uji individu diperoleh hasil bahwa nilai probabilitas untuk variabel kepemilikan manajerial lebih besar dari nilai signifikasni yang telah ditentukan yaitu sebesar 0.5371 , artinya bahwa variabel kepemilikan manajerial tidak memiliki pengaruh secara siginifikan terhadap profitabiltas yang diukur dengan Return On Assets (ROA). Hasil penelitian ini sejalan dengan Guna dan Herawaty (2010) yang menyatakan bahwa kepemilikan institusional, kepemilikan manajemen, komite audit, komisaris independen, independensi auditor tidak berpengaruh terhadap manajemen laba. Kemungkinan hal ini terjadi karena proporsi kepemilikan manajerial pada bank syariah sangatlah rendah sehingga pihak manajerial tidak memiliki wewenang dan pengaruh berarti dalam kebijakan perusahaan. 
Pada hasil uji variabel ukuran dewan komisaris independen (UDKI) menunjukkan pengaruh koefisien regresi negatif sebesar -0.027152 pada Return on Assets. Hasil tersebut menunjukkan bahwa apabila ukuran dewan komisaris independen meningkat sebesar $1 \%$ maka Return on Assets akan menurun sebesar 0.027152 skor dengan anggapan variabel yang lain konstan atau tetap. Dari hasil pengamatan pada hasil uji $t$ atau uji individu diperoleh hasil bahwa nilai probabilitas untuk variabel ukuran dewan komisaris independen lebih besar dari nilai signifikansi yang telah ditentukan yaitu sebesar 0.4025 , artinya bahwa variabel ukuran dewan komisaris independen tidak memiliki pengaruh secara siginifikan terhadap profitabiltas yang diukur dengan Return On Assets (ROA). Hasil penelitian ini sejalan dengan Tertius dan Christiawan (2015) yang berdasarkan hasil penelitian mereka ditemukan bahwa komisaris independen berpengaruh negatif signifikan terhadap ROA. Kemungkinan hal ini terjadi karena penempatan atau penambahan anggota komisaris independen hanya sekedar memenuhi ketentuan formal, sementara pemegang saham pengendali masih memegang peranan penting sehingga kinerja ukuran dewan komisaris independen tidak meningkat (Eliyanora dan Veronica, 2014)

Variabel ukuran dewan pengawas syariah (UDPS) merupakan variabel yang mempengaruhi Return on Assets dengan koefisien regresi negatif yakni sebesar -0.016574 . Hasil tersebut menunjukkan bahwa apabila ukuran dewan pengawas syariah meningkat sebesar $1 \%$ maka Return on Assets akan menurun sebesar 0.016574 dengan anggapan variabel yang lain konstan atau tetap. Dari hasil pengamatan pada hasil uji $\mathrm{t}$ atau uji individu diperoleh hasil bahwa nilai probabilitas untuk variabel ukuran dewan pengawas syariah lebih besar dari nilai signifikansi yang telah ditentukan yaitu sebesar 0.1537 , artinya bahwa variabel ukuran dewan pengawas syariah tidak memiliki pengaruh secara siginifikan terhadap profitabiltas yang diukur dengan Return On Assets (ROA). Hal ini terjadi kemungkinan karena Dewan Pengawas Syariah yang ditunjuk biasanya hanya berdasarkan popularitas dan tokoh masyarakat untuk menaikkan citra dari bank syariah itu sendiri (Rahmat, 2017). Hasil penelitian ini didukung oleh penelitian Agustina (2018) yang menemukan bahwa ukuran dewan pengawas syariah tidak berpengaruh signifikan terhadap earning management.

\section{SIMPULAN}

Berdasarkan hasil uji pengaruh Corporate Governance terhadap Kinerja Keuangan Bank Syariah di Indonesia yang menggunakan variabel independen kepemilikan manajerial, kepemilikan institusional, ukuran 
dewan komisaris independen dan ukuran dewan pengawas syariah serta Non Performing Financing (NPF) dan Return On Assets (ROA) sebagai variabel dependen, maka dapat ditarik kesimpulan sebagai berikut:

1. Kepemilikan Institusional tidak memiliki pengaruh secara signifikan terhadap risiko keuangan yang diukur dengan NPF. Hal ini dapat terjadi karena jika proporsi kepemilikan institusional rendah, maka akan rendah pula kesempatan bagi pemegang saham untuk dapat melakukan monitoring pada perusahaan sehingga tidak berpengaruh pada tingkat risiko kredit (NPF).

2. Kepemilikan manajerial tidak memiliki pengaruh secara signifikan terhadap risiko keuangan yang diukur dengan NPF. Hal ini dapat terjadi dikarenakan proporsi kepemilikan pihak manajerial pada bank syariah sangatlah rendah dikarenakan mayoritas perbankan syariah di Indonesia merupakan anak cabang dari perbankan konvensional sehingga mayoritas saham dimiliki oleh pihak Institusional.

3. Ukuran Dewan Komisaris Independen tidak berpengaruh secara signifikan terhadap risiko keuangan yang diukur dengan NPF. Hal ini disebabkan karena penempatan atau penambahan anggota komisaris independen dilakukan hanya sekedar untuk memenuhi ketentuan formal, sementara pemegang saham pengendali masih memegang peranan penting sehingga kinerja ukuran dewan komisaris independen tidak meningkat.

4. Ukuran Dewan Pengawas Syariah tidak berpengaruh secara signifikan terhadap risiko keuangan yang diukur dengan NPF. Hal ini terjadi karena Dewan Pengawas Syariah biasanya ditunjuk hanya berdasarkan popularitas tokoh dalam masyarakat untuk menaikkan citra dari bank syariah itu sendiri. Sehingga kinerja Dewan Pengawas Syariah di beberapa bank tidak terlalu berpengaruh.

5. Kepemilikan manajerial tidak memiliki pengaruh secara signifikan terhadap kinerja keuangan yang diukur dengan ROA. Hal ini dapat terjadi karena proporsi kepemilikan manajerial dalam perbankan syariah sangatlah rendah. Hal ini diakibatkan karena mayoritas perbankan syariah di Indonesia adalah anak cabang dari perbankan konvensional sehingga mayoritas saham dimiliki oleh pihak institusi.

6. Kepemilikan Institusional tidak memiliki pengaruh secara signifikan terhadap kinerja keuangan yang diukur dengan ROA. Hal ini terjadi karena apabila proporsi kepemilikan pihak institusional rendah, maka akan rendah pula kesempatan bagi pemegang saham untuk dapat melakukan monitoring pada perusahaan sehingga tidak berpengaruh pada tingkat profitabilitas (ROA).

7. Ukuran Dewan Komisaris Independen tidak berpengaruh secara signifikan terhadap kinerja keuangan yang diukur dengan ROA. Hal ini 
disebabkan karena komisaris independen ditempatkan hanya sekedar untuk memenuhi ketentuan formal undang-undang yang berlaku, sementara pemegang saham pengendali masih memegang peranan penting sehingga kinerja ukuran dewan komisaris independen tidak meningkat.

8. Ukuran Dewan Pengawas Syariah tidak berpengaruh secara signifikan terhadap kinerja keuangan yang diukur dengan ROA. Hal ini terjadi karena Dewan Pengawas Syariah ditunjuk bukan berdasarkan kemampuan mereka pada bidang terkait. Biasanya mereka ditunjuk hanya berdasarkan popularitas tokoh dalam masyarakat untuk menaikkan citra dari bank syariah itu sendiri. Sehingga kinerja Dewan Pengawas Syariah di beberapa bank tidak terlalu berpengaruh.

\section{Daftar Pustaka}

Abu Hussain, H., \& Al-Ajmi, J. 2012. Risk management practices of conventional and Islamic banks in Bahrain. The Journal of Risk Finance, 13(3), 215-239.

Agustia, Dian. 2013. Pengaruh Faktor Good Corporate Governance, Free Cash Flow, dan Leverage Terhadap Manajemen Laba. Jurnal Akuntansi dan Keuangan. Vol. 15, No. 1, 27-42.

Bourakba dan Zerargui. 2015. The relationship Between Credit Risk and Corporate Governance in Islamic Banking: An empirical study. Journal Business Management and Economics, Vol. 3, No. 4, 67-73.

Eksandy, A. 2018. Pengaruh Good Corporate Governance Terhadap Kinerja Keuangan Pada Perbankan Syari'ah Indonesia. Jurnal Akuntansi. Vol. 5, No. 1, 1-10.

Eliyanora dan Veronica Sylvia. 2014. Pengaruh Ukuran Dewan, Komisaris Independen dan Kepemilikan Institusional terhadap NPL. Jurnal Akuntansi UIN Syarif Hidayatullah. Vol 7 No 1.

Ghaffar. 2014. Corporate Governance and Profitability of Islamic Banks Operating in Pakistan. Interdisciplinary Journal of Contemporary Research in Business (IJCRB), Vol. 6, No. 6, 320 -336.

Gujarati Damodar \& Dawn Porter. 2013. Dasar-dasar Ekonometrika Buku 2. Jakarta : Salemba Empat.

Guna, Welvin I dan Arleen Herawaty. 2010. Pengaruh Mekanisme Good Corporate Governance, Independensi Auditor, Kualitas Audit dan Faktor Lainnya terhadap Manajemen Laba, Jurnal Bisnis dan Akuntansi. Vol. 12, No. 1, 53-68. 
Heenetigala dan Armstrong. 2011. The Impact of Corporate on Firm Performance in an Unstable Economic and Political Enviroment: Evidence from Sri Lanka. Financial Markets dan Corporate Governance Conference. Working Paper Series Social Science Research Network.

Khafid, Muhammad. 2012. Pengaruh Tata Kelola Perusahaan (Corporate Governance) dan Struktur Kepemilikan terhadap Persistensi Laba. Jurnal Dinamka Akuntansi. Vol. 4, No. 2, 138-148.

Magdalena, Septiana., Yuningsih, Isna., dan Lahaya, Ibnu Abni. 2017. Pengaruh Firm Size Dan Good Corporate Governance Serta Corporate Social Responsibility Terhadap Kinerja Keuangan Pada Bank Umum Syariah Di Indonesia. Jurnal EQUILIBRIUM. Vol. 5, No. 2, 221-238.

Maurya, Vishwa Nath, Rama Shanker Sharma, Saad Thalib Hasson Aljebori, Avadesh Kumar Maurya, Diwinder Kaor Arora. 2015. Correlation Analysis between the Corporate Governance and Financial Performance of Banking Sectors using Parameter Estimation. American Journal of Theoretical and Applied Statistics 4 (3): 27-32.

Mohammed dan Fatimoh. 2012. Impact of Corporate on Banks Performance in Negeria. Journal of Emerging Trends in Economics and Management Sciences (JETEMS), Vol. 3, No. 3, 257-260.

Paul. 2015. Impact of Corporate Governance on Financial Performance of Microfinance Bank in North Central Nigeria. International Journal of Humanities Social and Education (IJHSSE), Vol. 2, No.1, 153-170.

Permatasari. I dan Novitasary. R. 2014. Pengaruh Implementasi Good Corporate Governance Terhadap Permodalan dan Kinerja Perbankan di Indonesia: Manajemen Risiko Sebagai Variabel Intervening. Jurnal Ekonomi Kuantutatif Terapan, Vol.7, No.1, 52-59.

Rahmat, Biki Zulkifri, 2017, Optimalisasi Dewan Pengawas Syariah dalam pelaksanaan GCG di BPRS Harum Hikmahnugraha, Amwaluna, Vol. 1 No. 2.

Rehman, R dan I. Mangla. 2012. Does Corporate Governance Influence Banking Performance? Journal of Leadership, Accountability and Ethics, vol.9, No.3, 86-92.

Siswanti, Indra. 2016. Implementasi Good Corporate Governance Pada Kinerja Bank Syariah. Jurnal Akuntansi Multiparadigma. Vol. 7, No. 2, 156-323.

Sriwedari, Tuti. 2012. Mekanisme Good Corporate Governance, Manajemen Laba Dan Kinerja Keuangan Perusahaan Manufaktur Di Bursa Efek Indonesia. Jurnal Mediasi. Vol. 4, No. 1, 78-88. 
Switzer dan Wang . 2013. Default Risk Estimation, Bank Credit, and Corporate Governance. Journal Financial Markets, Institutiona dan Instruments, Vol. 22, No. 2, 91-112.

Syam, D. dan T. Nadja. 2012. Analisis Kualitas Penerapan Good Corporate Governance pada Bank Umum syariah di Indonesia serta Pengaruhnya Terhadap Tingkat Pengembalian dan Risiko Pembiayaan. Jurnal Reviu Akuntansi dan Keuangan, Vol. 2, No. 1, 195-203.

Tertius, Melia Agustina, Yulius Jogi Christiawan. 2015. Pengaruh Good Corporate Governance terhadap Kinerja Perusahaan pada Sektor Keuangan. Business Accounting Review 3 (1) Januari: 223-232.

Todorovic, I. 2013. Impact of corporate governance on performance of companies. Montenegrin Journal of Economics, 9(2), 47.

Wahyudin, Agus dan Badingatus Solikhah, 2017, Corporate governance implementation rating in Indonesia and its effects on financial performance, Emerald Insight, Vol. 17, No.2, pp 250-265.

Wati, Like Monisa, 2012, Pengaruh Praktek Good Corporate Governance terhadap Kinerja Keuangan Perusahaan di Bursa Efek Indonesia, Jurnal Manajemen, Vol. 01, No. 01. 